\title{
Entrepreneurship as a Tool for the Empowerment of Rural Women in India
}

\author{
${ }^{1}$ S.Pattu Meenakshi, ${ }^{2}$ Venkata Subrahmanyam C. V., ${ }^{3}$ Dr. K. Ravichandran \\ ${ }^{1}$ Research Scholar, Department of Management Studies,Madurai Kamaraj University, Madurai - 625021 \\ ${ }^{2}$ Research Scholar, Department of Entrepreneurship Studies,Madurai Kamaraj University, Madurai - 625021 \\ ${ }^{3}$ Professor \& Head, Department of Entrepreneurship Studies, Madurai Kamaraj University, Madurai - 625021
}

\begin{abstract}
Women are considered an important human resource of the nation and every state should try to utilize them as mediators of economic growth and development. Encouragement for women entrepreneurship is one of the ways for that. But unfortunately the traditional mind set of the society and negligence of the state and respective authorities is an important obstacle for the women entrepreneurship development in India. In spite of that women of today break all those obstacles and involve themselves in various sectors and proving their excellence. Major part of national economic development is contributed by rural economy. Rural women have to be initiated to step out of home and take responsibilities in the society. Entrepreneurship is considered to be a key for women empowerment especially in rural areas and hence promotion of women entrepreneurs is focused highly by the government.There is a need of continuous attempt to inspire, encourage, motivate and co-operate women entrepreneurs, awareness programs should be conducted on a mass scale with the intention of creating awareness among women about the various areas to conduct business. This paper gives a brief idea about the importance of entrepreneurship and its influence on the empowerment of rural women. Also it throws light on constrains of rural women entrepreneurs with solutions to overcome those.
\end{abstract}

Keywords: Women, Entrepreneurship, Rural India, Problems, development

\section{Introduction}

Entrepreneurship has assumed prime importance, both in research and in action, for accelerating economic growth. An entrepreneur is a critical factor who strives to reorient the national strategies and bring out the desired changes in the development pattern. Contrary to the earlier belief that entrepreneurs are a special creed and are born with special traits, entrepreneurship can be cultivated through proper training and financial support. An entrepreneur is a catalyst who can mobilize different resources and put them to effective use.

Women constitute the backbone of any nation. Prosperity of the nation depends upon the prosperity of its women. However, the role played by rural women in economic development has not been assigned sufficient importance.

The emergence of women entrepreneurs and their contribution to the national economy is quite visible in India. The number of women entrepreneurs has grown over a period of time, especially in the 1990s. Women entrepreneurs need to be lauded for their increased utilization of modern technology, increased investments, finding a niche in the export market, creating a sizable employment for others and setting the trend for other women entrepreneurs in the organized sector. While women entrepreneurs have demonstrated their potential, the fact remains that they are capable of contributing much more than what they already are. Women's entrepreneurship needs to be studied separately for two main reasons. The first reason is that women's entrepreneurship has been recognized during the last decade as an important untapped source of economic growth. Women entrepreneurs create new jobs for themselves and others and also by being different. They also provide the society with different solutions to management, organization and business problems as well as to the exploitation of entrepreneurial opportunities. The second reason is that the topic of women in entrepreneurship has been largely neglected both in society in general and in the social sciences. Not only have women lower participation rates in entrepreneurship than men but they also generally choose to start and manage firms in different industries than men tend to do.

\section{Status Of Rural Women In India}

Women used to command acute power and importance in our ancient culture. The proof of this fact can be found in all the scriptures and even our mythological stories. We worship Goddess Durga, Lakshmi, Saraswati and many others. That shows how Indian civilization had revered the female form. Things have not remained the same in last few decades or even centuries. The social fabric has acquired completely new dimensions. The women are considered less powerful and important than men yet situation is not entirely bleak.

Thanks to the efforts of government, NGOs, social welfare organizations and many such institutions, 
there has been a drastic improvement. Many private corporate bodies have also taken a keen interest in improving the economic status of women and the results are extremely encouraging. Pandit Jawaharlal Nehru had once said, "You can tell the condition of a nation by looking at the status of its women". We completely subscribe to this belief and steps are on its way to further improve the condition of rural women in India.

\section{Need for Rural Entrepreneurship}

Development of the society is directly related with the income generation capacity of its members. With agriculture as the key income generation activity the entrepreneurship based on farm and home can directly affect the income of a major chunk of our population. The growth of modernization processes such as industrialization; globalization; urbanization and migration further encourage it. Entrepreneurship on small scale is the only solution to the problems of unemployment and proper utilization of both human and non-human resources and improving the living conditions of the poor masses. The need for and growth of rural industries has become essential in a country like India because of the following reasons:

1. Rural industries generate large-scale employment opportunities in the rural sector as most of the rural industries are labor intensive.

2. Rural industries are capable of checking rural urban migration by developing more and more rural industries. 3. Rural industries/entrepreneurship help to improve the per capital income of rural people thereby reduces the gaps and disparities in income of rural and urban people.

4. Rural entrepreneurship controls concentration of industry in cities and thereby promotes balanced regional growth in the economy.

5. Rural entrepreneurship facilitates the development of roads, street lighting, drinking water etc. in the rural sector due to their accessibility to the main market.

6. Rural entrepreneurship can reduce poverty, growth of slums, pollution in cities and ignorance of inhabitants.

7. Rural entrepreneurship creates an avenue for rural educated youth to promote it as a career.

\section{Constraints Of Women Entrepreneurs}

Due to gender discrimination girls are socialized differently controlled by social norms, morals, beliefs,practices without any rights and decision making powers. Because of these reasons women entrepreneurs arefacing many constraints like lack of confidence, dual roles, rigid and male dominated market conditions etc.

\section{Constraints of Women Entrepreneurs Reasons and solutions}

\begin{tabular}{|c|c|c|c|}
\hline S.no & Constraints & $\begin{array}{l}\text { Reasons } \\
\end{array}$ & $\begin{array}{r}\text { Solutions } \\
\end{array}$ \\
\hline 1. & $\begin{array}{ll}\text { Lack } & \text { of } \\
\text { Confidence }\end{array}$ & $\begin{array}{l}\text { Due to differential socialization social norms, morals in } \\
\text { the family women lack confidence, support, decision } \\
\text { making powers needed for the growth of an entrepreneur. }\end{array}$ & $\begin{array}{l}\text { Social workers can develop the women } \\
\text { entrepreneurs within their reach by } \\
\text { extending the necessary inputs. }\end{array}$ \\
\hline 2. & $\begin{array}{l}\text { Over burden ness } \\
\text { due todual roles }\end{array}$ & $\begin{array}{l}\text { With the dual roles as, wife and mother women unable to } \\
\text { manage the enterpriseeffectively because of lack of time, } \\
\text { concentration and overburdened personal obligations. }\end{array}$ & $\begin{array}{l}\text { The family members like in-laws, husband } \\
\text { and others can share their responsibilities to } \\
\text { make them free to associate with an } \\
\text { enterprise. }\end{array}$ \\
\hline 3. & $\begin{array}{l}\text { Rigid and male } \\
\text { dominated } \\
\text { market } \\
\text { conditions }\end{array}$ & $\begin{array}{l}\text { Women, entrepreneurs have to depend, on their family } \\
\text { male members due to rigid male dominated market } \\
\text { conditions, lack of awareness, experience, and lobbing } \\
\text { capacities. }\end{array}$ & $\begin{array}{l}\text { The family members, NGO's GOS by } \\
\text { providing information about available } \\
\text { market opportunities, conditions and } \\
\text { services. }\end{array}$ \\
\hline 4. & Lack shoving & $\begin{array}{l}\text { Generally Indian women socialized with } \\
\text { femininequalities, withdrawal mentality, son preference, } \\
\text { and restricted movement. }\end{array}$ & $\begin{array}{l}\text { The most important shoving is self- } \\
\text { motivation, family support positive } \\
\text { Government Policies, timely finances and a } \\
\text { suitable environment to establish their } \\
\text { enterprises. }\end{array}$ \\
\hline 5. & $\begin{array}{l}\text { Lack of proper } \\
\text { training }\end{array}$ & $\begin{array}{l}\text { Indian families and societyprovide training to a girl to } \\
\text { make her as a good wife rather than to uplift her as an } \\
\text { entrepreneur she is not allowed to develop network with } \\
\text { other business men, which is considered as a sin and bad } \\
\text { culture. }\end{array}$ & $\begin{array}{l}\text { Equal opportunities, training, skill } \\
\text { development freedom to network with other } \\
\text { businessmen. }\end{array}$ \\
\hline 6. & $\begin{array}{l}\text { Lack of access to } \\
\text { financial support }\end{array}$ & $\begin{array}{l}\text { Because of societal mind women are not access to } \\
\text { finances like } \\
\text { (1) share in the property } \\
\text { (2) Government or private loans, schemes incentives, } \\
\text { etc. }\end{array}$ & $\begin{array}{l}\text { Equal share in the parental } \\
\text { property, access to private, } \\
\text { Government loans support and complete } \\
\text { information from other family members is } \\
\text { all walks of their life. }\end{array}$ \\
\hline 7. & $\begin{array}{l}\text { Lack of } \\
\text { exposure, } \\
\text { information } \\
\text { about training } \\
\text { programmes }\end{array}$ & $\begin{array}{l}\text { Due to illiteracy, restricted movement, lack of } \\
\text { networking, and awareness. }\end{array}$ & $\begin{array}{l}\text { Literacy is the main source of information } \\
\text { about all schemes and institutions which } \\
\text { will provide training, financial assistance } \\
\text { and about the enterprise and market } \\
\text { facilities. }\end{array}$ \\
\hline 8. & $\begin{array}{l}\text { Lack of access to } \\
\text { resources }\end{array}$ & $\begin{array}{l}\text { Withdrawal nature, societal zero paradise, hesitant nature } \\
\text { of women keeping them away from all resources }\end{array}$ & $\begin{array}{l}\text { Build the capacities to identify their } \\
\text { priorities and shed down the hesitations to } \\
\text { find a way to grab all kinds of resources. }\end{array}$ \\
\hline
\end{tabular}




\section{Entrepreneurship - A Tool In Empowering Rural Women.}

Empowering women particularly rural women is a challenge. Micro enterprises in ruralarea can help to meet these challenges. Micro - enterprises not only enhance nationalproductivity, generate employment but also help to develop economic independence,personal and social capabilities among rural women. Following are some of the personaland social capabilities, which were developed as result of taking up enterprise amongrural women.

- Economic empowerment

- Improved standard of living

- Self confidence

- Enhance awareness

- Sense of achievement

- Increased social interaction

- Engaged in political activities

- Increased participation level in Gram Sabha meeting

- Improvement in leadership qualities

- Involvement in solving problems related to women and community

- Decision making capacity in family and community

Economic empowerment of women by micro entrepreneurship led to the empowermentof women in many things such as socio-economic opportunity, property rights, political representation, social equality, personal right, family development, market development, community development and at last the nation development.

\section{$>$ Personal And Environmental Prerequisites For Entrepreneurial Development}

\begin{tabular}{|c|c|}
\hline Personal Prerequisites: & Environmental Prerequisites: \\
\hline $\begin{array}{l}\text { - Powerful urge } \\
\text { - Strong determination } \\
\text { - Hard work } \\
\text { - Risk bearing capacity } \\
\text { - Education } \\
\text { - Emotional maturity } \\
\text { - Knowledge: Attitude of the area population } \\
\text { i. Technical } \\
\text { ii. Legal } \\
\text { iii. Marketing } \\
\text { - Administrative skills } \\
\text { - Long sightedness. } \\
\text { - Innovativeness } \\
\text { - Ability to use available resources } \\
\text { - Previous experience/entrepreneurial parents }\end{array}$ & $\begin{array}{l}\text { - Availability of infrastructural facilities } \\
\text { - Venture capital availability } \\
\text { - Technically skilled labor } \\
\text { - Accessibility of suppliers } \\
\text { - } \begin{array}{l}\text { Proximity of } \\
\text { organization/Institution }\end{array}\end{array}$ \\
\hline
\end{tabular}

\section{How To Develop Women Entrepreneurs?}

Right efforts on from all areas are required in the development of women entrepreneurs and their greater participation in the entrepreneurial activities. Following efforts can be taken into account for effective development of women entrepreneurs.

1. Consider women as specific target group for all developmental programmers.

2. Better educational facilities and schemes should be extended to women folk from government part.

3. Adequate training programmed on management skills to be provided to women community.

4. Encourage women's participation in decision-making.

5. Vocational training to be extended to women community that enables them to understand the production process and production management.

6. Skill development to be done in women's polytechnics and industrial training institutes. Skills are put to work in training-cum-production workshops.

7. Training on professional competence and leadership skill to be extended to women entrepreneurs.

8. Training and counseling on a large scale of existing women entrepreneurs to remove psychological causes like lack of self-confidence and fear of success.

9. Counseling through the aid of committed NGOs, psychologists, managerial experts and technical personnel should be provided to existing and emerging women entrepreneurs. 
10. Continuous monitoring and improvement of training programmers.

11. Activities in which women are trained should focus on their marketability and profitability.

12. Making provision of marketing and sales assistance from government part.

13. To encourage more passive women entrepreneurs the Women training programmed should be organized that taught to recognize her own psychological needs and express them.

\section{Steps Taken By Government To Improve Position Of Women Entrepreneurs}

Keeping in view the contribution of small business to employment generation, balanced regional development of the country, and promotion of exports, the Government of India's policy thrust has been on establishing, promoting and developing the small business sector, particularly the rural industries and the cottage and village industries in backward areas. Governments both at the central and state level have been actively participating in promoting self-employment opportunities in rural areas by providing assistance in respect of infrastructure, finance, technology, training, raw materials, and marketing. Some of the support measures and programmes meant for the promotion of small and rural industries are discussed below:

\section{National Bank For Agriculture And Rural Development (NABARD)}

NABARD was set up in 1982 to promote integrated rural development. Since then, it has been adopting a multi-pronged, multi-purpose strategy for the promotion of rural business enterprises in the country. Apart from agriculture, it supports small industries, cottage and village industries, and rural artisans using credit and non-credit approaches. It offers counseling and consultancy services and organizes training and development programmes for rural entrepreneurs.

\section{The Rural Small Business Development Centre (RSBDC)}

It is the first of its kind set up by the world association for small and medium enterprises and is sponsored by NABARD. It works for the benefit of socially and economically disadvantaged individuals and groups. It aims at providing management and technical support to current and prospective micro and small entrepreneurs in rural areas. Since its inception, RSBDC has organized several programmes on rural entrepreneurship, skill up gradation workshops, mobile clinics and trainers training programmes, awareness and counseling camps in various villages of Noida, Greater Noida and Ghaziabad.

\section{National Small Industries Corporation (NSIC)}

This was set up in 1955 with a view to promote, aid and foster the growth of small business units in the country. This focuses on the commercial aspects of these functions.

$\circ \quad$ Supply indigenous and imported machines on easy hire-purchase terms.

- Procure, supply and distribute indigenous and imported raw materials.

- Export the products of small business units and develop export-worthiness.

$\circ \quad$ Mentoring and advisory services.

- Serve as technology business incubators.

- Creating awareness on technological up gradation.

- Developing software technology parks and technology transfer centers.

A new scheme of "performance and credit rating" of small businesses is implemented through National Small Industries Corporation (NSIC) with the twin objectives of (i) sensitizing the small industries about the need for credit rating and (ii) encouraging the small business units to maintain good financial track record.

\section{Small Industries Development Bank Of India (SIDBI)}

This has been set up as an apex bank to provide direct/indirect financial assistance under different schemes, to meet credit needs of small business organizations. It coordinates the functions of other institutions in similar activities; recommend measures considered necessary for improving the productivity of small enterprises in the informal sector; generate more employment opportunities on a sustainable basis, particularly in the rural areas and enhance the competitiveness of the sector in the emerging global environment

\section{Rural And Women Entrepreneurship Development (RWED)}

The Rural and Women Entrepreneurship Development programme aims at promoting a conducive business environment and at building institutional and human capacities that will encourage and support the entrepreneurial initiatives of rural people and women. RWE provides the following services:

- Creating a business environment that encourages initiatives of rural and women entrepreneurs.

- Enhancing the human and institutional capacities required to foster entrepreneurial dynamism and enhance productivity.

○ Providing training manuals for women entrepreneurs and training them. 
- Rendering any other advisory services.

\section{World Association For Small And Medium Enterprises (WASME)}

It is the only International Nongovernmental Organization of micro, small and medium enterprises based in India, which set up an International Committee for Rural Industrialization. Its aim is to develop an action plan model for sustained growth of rural enterprises.

Apart from these, there are several schemes to promote the non-farm sector, mostly initiated by the Government of India. For instance, there are schemes for entrepreneurship through subsidized loans like Integrated Rural Development Programme (IRDP), Prime Minister RojgarYojana (PMRY), schemes to provide skills like Training of Rural Youth for Self Employment (TRYSEM), and schemes to strengthen the gender component like Development of Women and Children in Rural Areas (DWCRA).

\section{Scheme Of Fund For Regeneration Of Traditional Industries (SFURTI)}

To make the traditional industries more productive and competitive and to facilitate their sustainable development, the Central Government set up this fund with Rs. 100 crores allocation to begin within the year 2005. This has to be implemented by the Ministry of Agro and Rural Industries in collaboration with State Governments. The main objectives of the scheme are as follows:

- To develop clusters of traditional industries in various parts of the country;

- To build innovative and traditional skills, improve technologies and encourage public-private partnerships, develop market intelligence etc., to make them competitive, profitable and sustainable; and

- To create sustained employment opportunities in traditional industries.

\section{The District Industries Centers (DICs)}

The District Industries Centers Programme was launched on May 1, 1978, with a view to providing an integrated administrative framework at the district level, which would look at the problems of industrialization in the district, in a composite manner. In other words, District Industries Centers is the institution at the district level which provides all the services and support facilities to the entrepreneurs for setting up small and village industries.

\section{Role of SHGs In Promoting Entrepreneurship Among Rural Women}

Organizing the poor into groups however is not an easy task. The Non-Governmental Organizations play a crucial role to identify the self-interested persons, to form them into self-help groups and guide the members in farming the rules and regulations with regard to thrift and credit procedures and repayment ethics. India has a long tradition of people coming together voluntarily for performing various socio-cultural, religious and economic activities collectively. It is a voluntary association of women formed to attain certain collective goals. The Self Help Group is a viable alternative to achieve the objectives of rural development and to get community participation in rural development programmes. Generally it has members not exceeding 20 and one member act as a leader called animator. Credit needs of the rural women are mostly fulfilled through SHGs. It enhances status of women as participants, decision makers and beneficiaries in the democratic, economic, social and cultural spheres of life.

The role of micro-credit is to improve the socio economic status of women in households andcommunities. The micro entrepreneurship is strengthening the women sustainable development and removes the gender inequalities. Self Help Group's saving are extended as micro credit to its members to promote the micro and small scale enterprises to alleviate poverty and to provide sustainable economic development of the community. Women constitute 90 per cent of total marginal workers of the country. Rural women are playing a direct and indirect role both in farm operations and domestic chores. Besides they are capable to manage the livestock activities with their savings and are able to increase the income levels of their families, and community. Now a days rural women are achieving sustainable development by associating with the technical know- how and are able to cope up with the changing scenario of the production field. By acquiring new skills they are able to setting their own enterprises for their sustainable development and also they are able to develop other women of their villages. Majority of the SHG women of rural areas and urban areas are managing micro enterprises with livestock and domesticated activities because they can be managed with micro finances. Very few are associated with agriculture and its allied activities. It is evident that micro entrepreneurs will have continuous income and can contribute to their sustainable development.

\section{Conclusion}

Entrepreneurship among women, no doubt improves the wealth of the nation in general and of the family in particular. Women today are more willing to take up activities that were once considered the preserve of men, and have proved that they are second to no one with respect to contribution to the growth of the 
economy. Women entrepreneurship must be molded properly with entrepreneurial traits and skills to meet the changes in trends, challenges global markets and also be competent enough to sustain and strive for excellence in the entrepreneurial arena. It is quite clear that rural entrepreneurship cannot be developed without significant training. Therefore, instead of just schemes (financial and developmental) as the carrot for entrepreneurship development an intensive training needs to be provided to the youth in rural India. What's required is to create a devoted team to take up rural entrepreneurship training as per integrated rural development program. Rural entrepreneurship is the answer to removal of rural poverty in India. Therefore, there should be more stress on integrated rural development programs. The problem is that most of the rural youth do not think of entrepreneurship as the career option. Therefore, the rural youth need to be motivated to take up entrepreneurship as a career, with training and sustaining support systems providing all necessary assistance.

\section{References}

[1]. http://www.preservearticles.com/201101143354/need-for-rural-entrepreneurship.html

[2]. http://www.ncbi.nlm.nih.gov/pubmed/12279418

[3]. http://www.indianchild.com/women of rural india.htm

[4]. http://www.enotes.com/business/q-and-a/whar-major-problems-faced-by-women-entrepreneurs-55369

[5]. http://www.publishyourarticles.net/knowledge-hub/entrepreneurship/10-major-problems-faced-by-women-entrepreneurs-inindia.html

[6]. http://www.thehindubusinessline.com/opinion/article3532982.ecehttp://www.isrj.net/june/2011/Economic_WOMEN_ENTREPREN URSHIP_PROBLEMS_AND_PROSPECTS_OF_INDIAN_ECONOMY.html

[7]. http://www.aygrt.net/PublishÄrticles/630.aspx

[8]. http://www.eurofound.europa.eu/ewco/2005/10/EE0510NU02.htm

[9]. http://www.management-issues.com/2006/11/15/research/rural-women-more-likely-to-be-entrepreneurs.asp 